\title{
Effects of Sand/Gravel Mining in Minna Emirate Area of Nigeria on Stakeholders
}

\author{
Lawal P.O (PhD; FNIQS) \\ Department of Quantity Surveying \\ Federal University of Tech; Minna, Nigeria
}

Tel: 234-803-453-1271 E-mail: lawalp@futminna.edu.ng, lawalp4christ@yahoo.co.uk

\begin{abstract}
The paper examined sand and gravel mining activities both on land and the rivers as a business venture in Minna emirate council of Niger state, Nigeria. It identified various stakeholders in this business as: the landlords of the quarries, the local government authorities and the miners among others. It further looked at what each stakeholder stands to gain or lose in the business. Quantitative data were collected on the direct financial benefits from the quarrying work and the analysis of these data, using percentages, showed that while the quarry owner and the local government put together earn less than 8 percent of the total profit accruing from the business, the miner ferries away over 92 percent of the accrued revenue. It was recommended that repairs should be made to the exploited mines and that government agents in charge of the quarries should be more responsive to the movements in the market prices of the commodity.
\end{abstract}

Keywords: Ecosystem, Fauna, Gravel, Quarry, Revenue, Sand, Stakeholder

\section{Introduction}

For thousands of years, sand and gravel have been used in the construction of roads, dams and buildings (The Ojos Negros Research Group, 2008). Major constituents of any of these structures, by volume or weight, are the aggregates (sand and stone). Very few structures in their permanent forms are made without the aggregates. Today demand for sand and gravel continues to increase at a geometric dimension. Before these aggregates get incorporated into the structures, they undergo series of processes which entail multiple handling, involving various types and grades of labour and machines. This doubtlessly gives rise to a multiplier effect on the socio economic life of the society (Idiake, 2006). Many people get employed more families have increased income and so on. As a matter of facts, NIOSH (2003) asserted that in 2001 alone, a total of 7,131 sand and gravel mining operations reported employment statistics to the Mine Safety and Health Administration (MSHA) in its area of jurisdiction. The unanswered question however, is: at what expense to the environment and consequently to the inhabitants and other stakeholders are these multiplier effects being achieved?

Focus of the study is on the challenges posed by the sand/gravel mining activities to the stakeholders. The stakeholders identified for the study include, the land owners of the quarry sites, the local government authorities (LGAs) in whose jurisdictions the quarries are domiciled, the Niger State government of Nigeria, the farmers who might cultivate the land for crop or graze their cattle therein, the wildlife community whose habitat is the subject of the mining activities and who eventually have to migrate, the aquatic community members in the affected rivers and finally, the miners. The study was carried out during January 2008 and only in Chanchaga \& Bosso LG.areas of the Minna emirate. The period under investigation spanned the five year period $2003-2007$. The mine sites and rivers involved in the study include Maitumbi, Sarikin pawa, Gidan kusa, Rafin tofa, Nykangbe river, River Chanchaga and Rafin Dogo.

\subsection{The Research Questions}

Sand/Gravel mining activities generate revenue, but, as stated earlier, to what extent do the stakeholders benefit in the revenue sharing formula? What contribution does the mine site make to the environmental ecosystem?

\section{Construction in Minna Emirate Council of Nigeria}

Construction activities in Minna emirate of Niger State Nigeria, predated its existence as an emirate though, the creation of Niger State in 1976 raised the level of the activities to a sensitive level when Minna found itself saddled with the responsibility of becoming a state capital. The responsibility attracts gains and pains which are on both short and long term bases. These gains and pains are both tangible and intangible in nature and doubtlessly sizeable in dimension.

The sand/gravel mining activities in the emirate began to assume an enormous dimension at the tail end of the last millennium when the civilian administration at the national level threw open the floodgate of schemes for home 
ownership. These schemes came via the various releases of fund such as the increases in the workers salaries (minimum wage increase) loans for housing, furniture, vehicle refurbishment and the revived national housing scheme.

Minna Emirate comprises of, as at January 2008, five local government councils (LGC) and three Area Development Councils (ADC). These are respectively: Bosso, Chanchaga, Munya, Paikoro, Shiroro, Kaffi, Lapkma and Minna West.

\section{Facts about Mining Effects on the Environment}

Although sand mining is expected to be regulated by law in many places, Whitehead (2007) opined that it is still many a times done illegally It is rapidly becoming an ecological problem as the demand for sand increases in industry and construction (Wikipedia, 2008; Whitehead, 2007). The environmental devaluation that is an aftermath of man's activities such as sand/gravel mining on land include disturbance of the landscape, ugly/distorted topography, agriculturally unproductive terrain, creation of pools of water for breeding pests, deforestation and general degrading of the ecosystem with air/land/water pollution. Environment as used in this context has three components namely:

i. The sum total of external condition in which the organisms exist.

ii. The organisms themselves including the floral and faunal community and

iii. The physical surroundings such as land forms.

All of these three including water, human and geo-morphological features are adversely affected by the sand/gravel mining activities. Wikipedia (2008) and Alexander \& Hansen (1983) listed as part of negative impact on the environment, the following: (a). disturbance to aquatic ecosystem, (b). increase in turbidity which in turns can affect aquatic species metabolism and interfere with spawning and (c) tertiary impacts to fauna.

Aside petroleum exploration which brings the greatest pollution to the southern Nigerian environment, especially the Niger Delta region, hazards on the environment brought about by sand/gravel mining activities are also very big and damaging (Adekoya, 1995; UNESCO /Mab, 1995; Aigbedon, 2005). Noise generated within the immediate surrounding area in the course of blasting, quarrying and crushing the rocks can do and does a lot of damages to some of the stakeholder groups. For instance rock blasting causes ground vibration (Mbamali, 2007). The vibration can give rise to other ugly developments such as land slide or earth tremors. Generally the noise frightens away part of the fauna in such a locality. The deliberate deforestation of an area for mine development may cause the elimination of some plants and exodus of some animal/bird species that feed on such plants or depend on them for cover (Bayley \& Baker, 2000; Adekoya, 2003; Jacobson, 2004; Adepelumi et al, 2006; Aigbedon.\& Iyayi, 2007).

In many localities, particularly near centres of heavy construction works large granite and gneiss inselbergs with their delightful scenic view are now being pulled down to produce coarse aggregates for construction work (roads and buildings). Typical scenes in Niger state, like around Zuma rock on Zuba-Kaduna road may not draw much attention to the emirates gravel/sand mining environmental degrading activities until one comes to the Maitumbi, Maikunkele and Sarkin Pawa areas of the emirate.

The extensive mining of these building materials in the emirate naturally results in fluctuation of ground water level which in turn, according to Martin (2003) and Bashir \& Adebayo (2002), leads to considerable variations in the concentration of geo-chemical and bacteriological pathogens in the water. Very importantly, according to Kondolf et al (2001), this extensive mining brings about the lowering of alluvial water tables, channel destabilization and loss of aquatic and riparian habitat

\section{Methods}

The method adopted for the collection of data for the study include interview of some of the stakeholders viz: local government officials in charge of mining sites, miners of gravel and sand and end consumers of the commodities. The interviews were mainly on financial implications of the mining activities as the particular stakeholders were affected. Specifically, the government officials (the Revenue Clerks from the Accounts Department of each LGC/ADC) were requested to supply the figures of the amount of money charged each tipper by the local government per trip. The data were supplied with duplicate copies of the issued receipts sighted in the files.

Mines in Maitumbi, Maikunkele and Minna western bypass were visited and the tipper drivers along with the miners were asked the amount they usually pay to the quarry owners for each tipper load extracted. The figures they gave were later corroborated by the quarry owners. It is to be noted that the miners and the tipper drivers were 
working as a team. It is also to be noted here that rivers do not belong to individual owners. The information collected was tabulated and analyzed using percentages and ratios.

\section{Analysis}

From Table 1, it was observed that the amount paid by the miner to either the local government or to the quarry site owner was a constant figure of 25 per tipper load through the five year period while the consumer of the commodity paid varying annual prices to the miner in the same period covered by the study. This shows that the miners were in total control of the level of financial benefit accruing to each participating stakeholder. It also shows that while the miners were responsive to changes in general market prices of commodities, the local government and the quarry owners were not. Neither the local governments nor the landlords of the mines could take up the responsibility of determining the prices of their wares.

This observation portrays a typical Nigerian government authority's stance whereby changes in government tariffs become operative only after the necessary laws or edicts are enacted. The case of the quarry site owners and the local government shows either nonchalance, lack of knowledge of movement in market values of the product or inadequate backing from local authority to increase loading charges.

Table 2 portrays the average annual earnings of the three main participants in the mining activity. The quarry owner's earnings stand at $\$ 366800$ over the five year period while the local government authority receives 45 000. Similar figure for the miner is $\$ 448200$ out of the total generated revenue of $\$ 260000$. In proportion to the total generated revenue, the earnings respectively, are in the ratios of 8.15: 1.00: 107.74 for the three principal actor groups.

From Tables 3, it could be seen without ambiguity, that the earnings the quarry owner derives from the business oscillates around seven percent average while the local government contends with less than one percent. The miner carts away, on the average, about ninety-two percent of the total income generated from the mine.

It could further be observed that, over the five year period, as the total revenue generated increases, the percentage of the revenue accruing to either the quarry owner or the local government decreases. On the other hand the miner's shear of the revenue over the period increases with the increase in the total generated revenue. The miner's proportion of the total revenue oscillated between 90 and 94 percent.

\section{Comments/Recommendations}

\subsection{Comments on River Mining in the Emirate}

The complete removal of vegetation and destruction of the soil profile destroys habitats above and below the ground as well as within the aquatic ecosystem, resulting in the reduction in faunal populations.

In-stream sand mining results in the destruction of aquatic and riparian habitat through large changes in the channel morphology. Impacts include bed degradation, bed coarsening, lowered water tables near the streambed, and channel instability. These physical impacts cause degradation of riparian and aquatic biota and may lead to the undermining of bridges and other structures. Continued extraction of these minerals (aggregates) may cause the entire streambed to degrade to the depth of excavation. Sand/gravel mining generates extra vehicle traffic, which negatively impairs the environment. Where access roads cross riparian areas, the local environment may be impacted upon.

Excessive in-stream sand-and-gravel mining causes the degradation of rivers. In-stream mining lowers the stream bottom, which may lead to bank erosion. Excessive in-stream sand mining is a threat to bridges, river banks and nearby structures. Sand mining also affects the adjoining groundwater system and the uses that local people make of the river.

In-channel or near-channel sand-and-gravel mining changes the sediment budget, and may result in substantial changes in the channel hydraulics. These interventions have variable effects on aquatic habitat, depending on the magnitude and frequency of the disturbance, mining methods, particle-size characteristics of the sediment, the characteristics of riparian vegetation, and the magnitude and frequency of hydrologic events following the disturbance. Well-documented cases and related field data are required to properly assess physical, biological, and economic tradeoffs.

Suffice it to say that in-stream mining can have other costly effects beyond the immediate mine sites. Many hectares of fertile streamside land can be lost annually as well as valuable timber resources and wildlife habitats in the riparian areas. Degraded stream habitats result in loss of fisheries productivity, biodiversity, and recreational potential. Severely degraded channels may lower land and aesthetic values. 
All species require specific habitat conditions to ensure long-term survival. Native species in streams are uniquely adapted to the habitat conditions that existed before humans began large-scale alterations. These have caused major habitat disruptions that favored some species over others and caused overall declines in biological diversity and productivity. It is understood that in most streams and rivers, habitat quality is strongly linked to the stability of channel bed and banks. This then implies that unstable stream channels are inhospitable to most aquatic species.

\subsubsection{Stability of Structures}

Sand-and-gravel mining in stream channels can damage public and private property. Channel incision caused by gravel mining can undermine bridge piers and expose buried pipelines and other infrastructure. Several studies have documented the bed degradation caused by in-stream mining. Head-cutting mobilizes substantial quantities of streambed sediments which are then transported downstream to deposit in the excavated area and locations further downstream.

Channel incision increases stream bank heights, resulting in bank failure when the mechanical properties of the bank material cannot sustain the material weight. Mining-induced bed degradation and other channel changes may not develop for several years until major channel-adjustment flows occur, and adjustments may continue long after extraction has ended.

\subsubsection{Groundwater and Water Quality}

Apart from threatening bridges, sand mining transforms the riverbeds into large and deep pits; as a result, the groundwater table drops leaving the drinking water wells on the embankments of these rivers dry. In-stream sand mining activities will have an impact upon the river's water quality. Impacts include increased short-term turbidity at the mining site due to re-suspension of sediment, sedimentation due to stockpiling and dumping of excess mining materials and organic particulate matter, and oil spills or leakage from excavation machinery and transportation vehicles. Suspended solids may adversely affect water users and aquatic ecosystems resulting in high chance of poisoning of aquatic life. The impact on human life is particularly significant if water users downstream of the site are abstracting water for domestic use.

\subsection{Recommendations}

To minimize the negative impact of sand/gravel on the emirate environment, the following recommendations are made:

Indiscriminate opening up of plots for sand or gravel mining should be discouraged by appropriate local authorities.

The state government should evolve a policy compelling the explorers/ miners of these construction materials to reinvest and repair the old (disused) mine sites. Such reinstatement activities can go a long way at reducing the chance for occurrence of landslide or earth tremor in the locality. After all it is a common knowledge that resources required for the amelioration of the badly managed environment is prohibitive in relation to the benefits derived from the excessive exploration of the environment. Lastly the government officials in charge of pricing of the quarrying business should take cognizance of the movement of prices in the market and make their prices to be dynamic, responding to the economic level that is in operation in the environment.

\section{References}

Adekoya, J.A. (1995). Negative environmental impact of mineral exploration in Nigeria. International Journal of Physical Sciences, $613-619$.

Adekoya, J.A. (2003). Environmental effect of solid minerals mining. Journal of Physical Sciences, Kenya; 625 640.

Adepelumi, A.A; Solanke, A.A; Sanusi, O.B and Shallangwa, A.M. (2006). Model tank electrical resistively characterization of LNAPL migration in a clayey-sand formation. Environmental Geology; 50. 1221 - 1233.

Aigbedon, I.N. (2005). Environmental pollution in Niger Delta Nigeria. Inter-Disciplinary Journal. Enugu, Nigeria; 3 (4); $205-210$.

Aigbedon,I.N.\& Iyayi, S.E. (2007). Environmental effect of mineral exploration in Nigeria. International Journal of Physical Sciences; 2 (2), 033 - 038. [Online] Available: www.academicjournals.org/IJPS (September $25,2010)$.

Alexander, G.R. \& Hansen, E.A. (1983). Sand sediment in a Michigan trout stream. Part 2. Effects of reducing bedload on a trout population. North American Journal of Fisheries Management. 3: 365 - 372. [Online] Available: www.fws.gov/.../Gravel-Mining-SedimentRemovalBibliography-pdf (November 8, 2010). 
Bashir B.A. \& Adebayo A.A. (2002). Seasonal variations in water quality and occurrence of water borne diseases in Yola Area, Nigeria Journal of Environmental Sciences. 6 26- 32.

Bayley, P.B. \& Baker, C.F. (2000). Floodplain restoration in off-channel habitats used for gravel mining in the Williamette River basin. [Online] Available: www.fws.gov/oregonfwo/...../GravelMining-sedimentRemoval... (November 8, 2010).

Idiake J.E. (2006). The effects of macro-economic variables on private residential housing development in Minna, Niger State. Journal of Environmental Sciences 10.(1) $146-152$.

Jacobson, R.B. (2004). Watershed sustainability: Downstream effects of timber harvest in the Ozarks of Missouri, in Flader, S.J. ed, Toward sustainability for Missouri Forest. USDA Forest Service North Central Research Station, General Technical Publication NC-239, 106 - 128.

Kondolf, G.M; Smeltzer, M. and Kimball, L. (2001). Freshwater gravel mining and dredging issues. White paper prepared for the Washington Departments of Fish and Wildlife, Ecology, and Transportation. Olympia. [Online] Available: http://www.wdfw.wa.gov/hab/ahg/freshdrg.pdf (November 8, 2010).

Martin, Y. (2003). Evaluation of bed load transport formula using field evidence from the Vedder River, British Columbia. Geomorphology 53: 75 - 95.

Mbamali, I. (2007). Stone quarrying in Nigeria: an overview of necessary initiations towards a sustainable built environment. Construction Focus 1(2), 29 - 35.

NIOSH, (2003). Sand and gravel mining facts. NIOSH Publication No 2003 - 134, July 1 - 2. [Online] Available: www.cdc.gov/niosh/mining/pubs/pubreference (November 20, 2008).

The Ojos Negros Research Group, (2008). Sand mining facts. [Online] Available: http://threeissues.sdsu.edu/three_issues_sandminingfacts (January 16, 2009)

(UNESCO /Mab, (1995). Examination of human impacts on a specific ecosystem. Regional Training Workshop; Akure, Nigeria. 23 - 26 July, $314-323$.

Whitehead, G.J. (2007). Land and environment: sand mining. [Online] Available: http://localhistory.kingston.vic.gov.au/htu (November 9, 2010).

Wikipedia, (2008). Wikipedia Forever sand mining. [Online] Available: http://en.wikipedia.org/wiki/sand_mining (November 20, 2008)

Table 1. Unit rate of mined sand (3m3 Tipper load)

$\begin{array}{ll}\text { Year } & \begin{array}{l}\text { No of } 3 \mathrm{~m} 3 \text { tipper } \\ \text { loads/year }\end{array}\end{array}$

$\begin{array}{lllll} & & \begin{array}{l}\text { To plot owner } \\ \text { By Miner }\end{array} & \begin{array}{l}\text { To LG* } \\ \text { By Miner }\end{array} & \begin{array}{l}\text { By end user to } \\ \text { Miner }\end{array} \\ 2003 & 1800 & 200 & 25 & 2300 \\ 2004 & 1800 & 200 & 25 & 2500 \\ 2005 & 1820 & 200 & 25 & 3000 \\ 2006 & 1850 & 200 & 25 & 3000 \\ 2007 & 1900 & 200 & 25 & 3500\end{array}$

Source: Field survey to the Chanchaga \& Bosso LG areas, 2008

*Payment to the LG was arrived at, using the assumption that a tipper makes an average of 2 trips to a mine daily. 
Table 2. Annual earnings from mined sand

\begin{tabular}{|c|c|c|c|c|c|}
\hline \multirow[t]{2}{*}{ Year } & \multirow{2}{*}{$\begin{array}{l}\text { No of } 3 \mathrm{~m} 3 \\
\text { tipper loads }\end{array}$} & \multirow{2}{*}{$\begin{array}{l}\text { Total income } \\
\text { from mining } \\
\text { (A) }\end{array}$} & \multicolumn{3}{|c|}{ Total income received by } \\
\hline & & & $\begin{array}{c}\text { Plot owner } \\
\text { (N) }\end{array}$ & $\begin{array}{l}\mathrm{LG} \\
\quad(\mathbf{N})\end{array}$ & The miner \\
\hline 2003 & 1800 & 4140000 & 360000 & 45000 & 3735000 \\
\hline 2004 & 1800 & 4500000 & 360000 & 45000 & 4095000 \\
\hline 2005 & 1820 & 5460000 & 364000 & 45000 & 5051000 \\
\hline 2006 & 1850 & 5550000 & 370000 & 45000 & 5135000 \\
\hline 2007 & 1900 & 6650000 & 380000 & 45000 & 6225000 \\
\hline \multicolumn{2}{|c|}{ Average } & 5260000 & 366800 & 45000 & 4848200 \\
\hline
\end{tabular}

Source: Table 1

Table 3. Stakeholders' Proportions of Earnings from Mining Activities

\begin{tabular}{|c|c|c|c|c|}
\hline \multirow[t]{2}{*}{ Year } & \multirow{2}{*}{$\begin{array}{l}\text { Total income from } \\
\text { mining } \\
\text { (N) }\end{array}$} & \multicolumn{3}{|c|}{ Percentages of income accruing to: } \\
\hline & & Plot owner & LG & The miner \\
\hline 2003 & 4140000 & 8.70 & 1.09 & 90.21 \\
\hline 2004 & 4500000 & 8.00 & 1.00 & 91.00 \\
\hline 2005 & 5460000 & 6.67 & 0.82 & 92.51 \\
\hline 2006 & 5550000 & 6.67 & 0.81 & 92.52 \\
\hline 2007 & 6650000 & 5.71 & 0.68 & 93.61 \\
\hline Average & 5260000 & 7.15 & 0.88 & 91.97 \\
\hline
\end{tabular}

Source: Table 2 


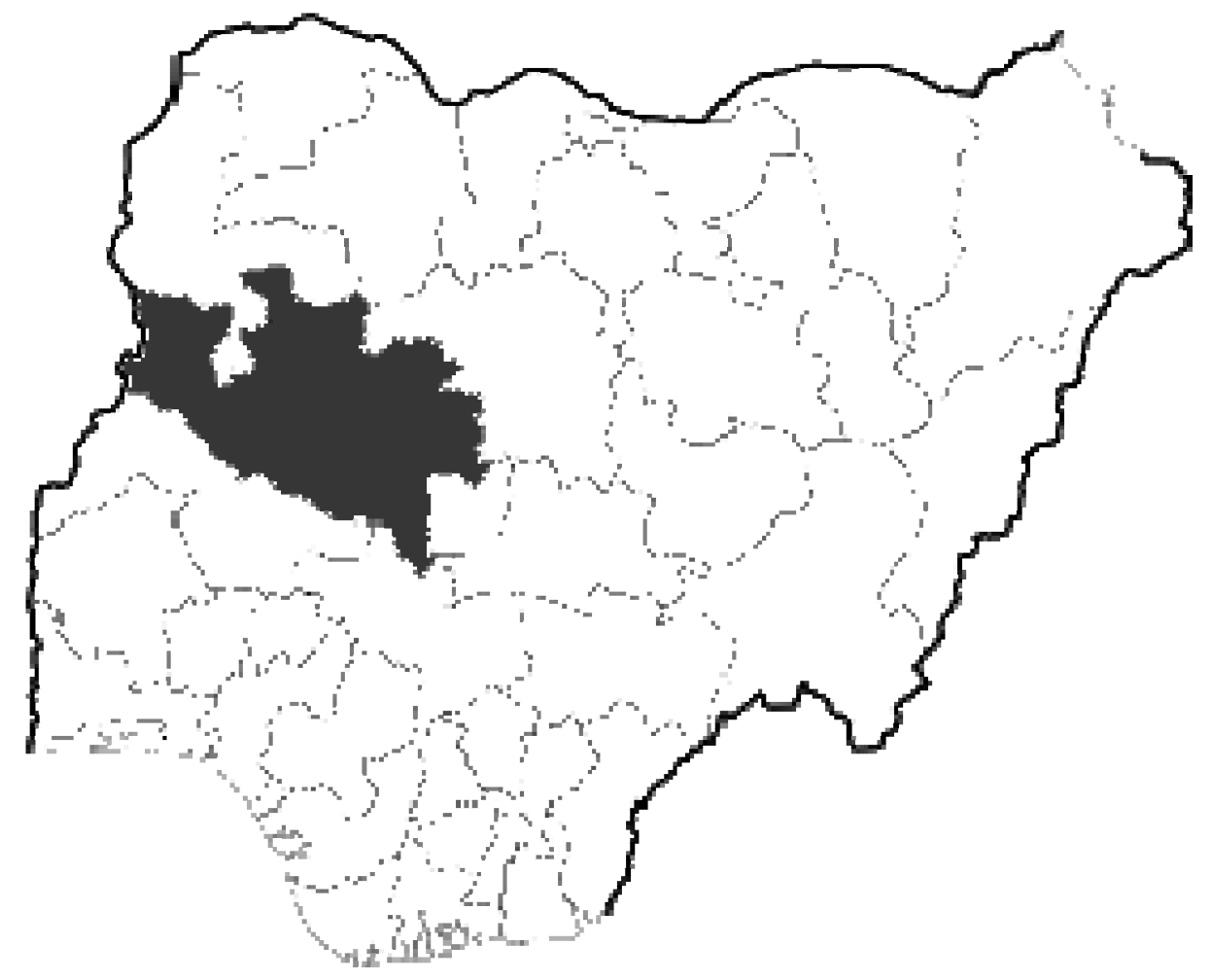

Figure 1. Map of Nigeria showing Niger State (the Study Area)

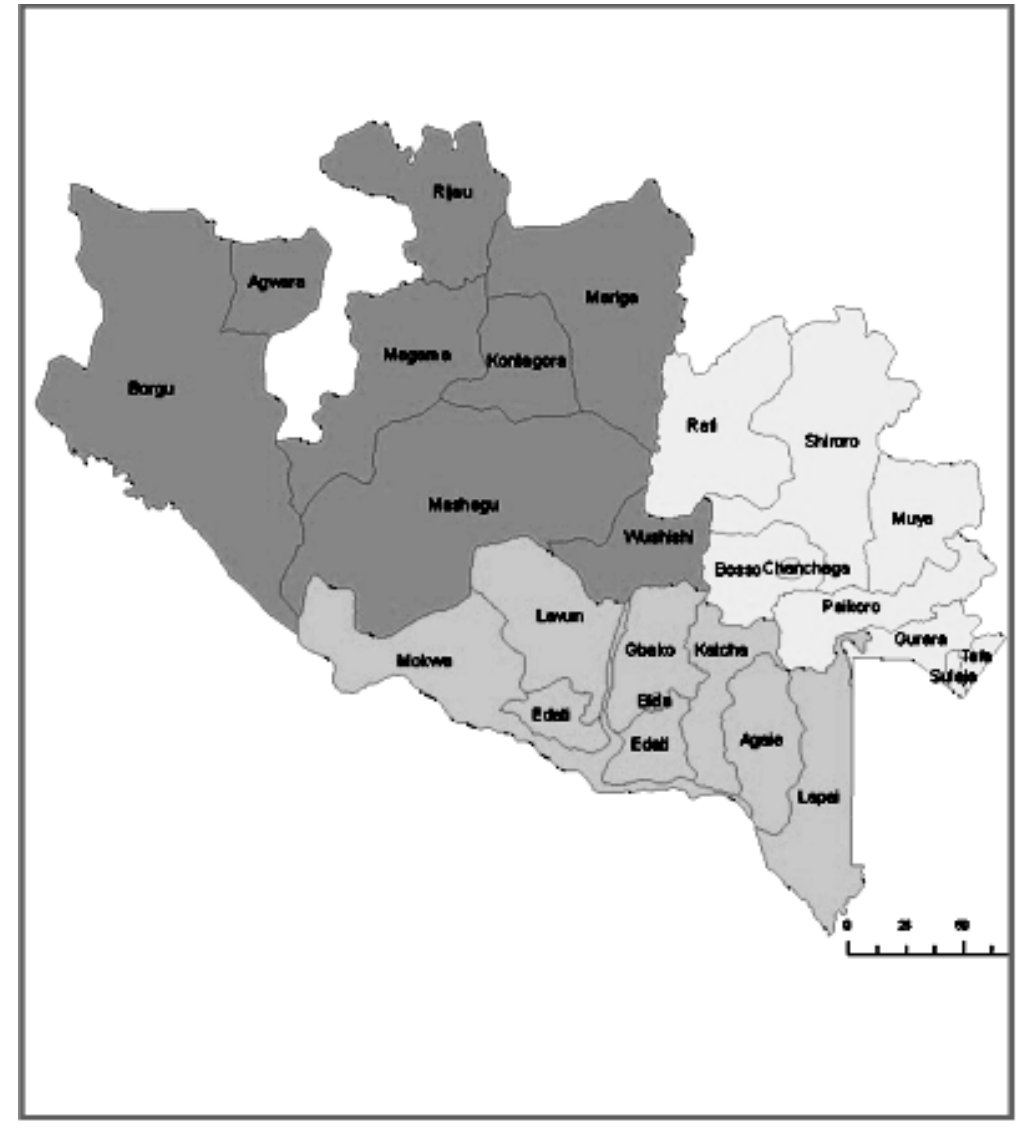

Figure 2. Map of Niger State by Local Government Areas 